\title{
correspondence
}

\section{Jukes on food}

SIR,-Thomas H. Jukes, writing on nutrition (May 13, page 92), tried to be funny at the expense of accuracy. To give but one example, his response to the recommendation from the Royal College of Physicians' Working Party that less butter should be eaten, is that it is "just as logical" to place a warning on "every nubile woman, for human milk contains fats similar to those in cow's milk and we are told the prearteriosclerotic changes can start at a very young age".

Really, Mr Nature, this sort of stuff will not do. Cow's milk is suited to body growth, with three times as much protein and mineral as human milk which, by contrast, is suited to brain, vascular and organ biochemistry. Human milk contains between 4-7 times the amount of essential polyunsaturated fatty acids of 18 carbon chain length, and some 8-12 times the amount of long-chain polyunsaturated fatty acids (C20-C22), which are the principal essential fatty acids found in the brain, artery, endocrine and reproductive systems of the body. Perhaps Thomas Jukes had not noticed that the brains and arteries of the human are somewhat differently developed as compared with those of the cow.

$$
\text { M. A. Crawford }
$$

The Zoological Society of London

\section{Government and industry}

SIR,-Since you have dealt editorially (April 29) with the difficult question of salary comparisons between industry and the civil service, I would seek space to make only two points in reply to Harold Turner (April 8, page 472).

First, I agree with him that the problems of British industry are not primarily technological, but economic and managerial. My article (February 12, page 436) was intended to be a constructive contribution to solving these more serious problems. Second, the CBI has devoted considerable thought to defining the optimum relationship between government and industry in the field of research and technology, and last October sent a fairly lengthy, and generally wellreceived, document on the subject to appropriate parts of the government machine.

There is no simple formula, but essentially the CBI sees the need to develop government-industry techno- logical relations through such mechanisms as the Requirements Boards of the Department of Industry, and to establish links between these Boards and the Economic Development Committees which operate under NEDC in order to relate technological to economic factors.

\section{Isolative sound-change}

SiR,-Your correspondents Alan Ross (April 22, page 664) and Ian Hurrell (May 13, page 93) discuss the problem of vowel-shifts with particular reference to the evolution of the English language. We must first of all be certain that a problem exists.

"Anglo-Saxon" is the name given to the miscellany of people who migrated to the British Isles from all of the coastal regions around the North Seafrom what is now Flanders to northern Scandinavia. The languages and dialects of these peoples, which fused to become the dialects of the Anglo-Saxon language, were related but diverse. Both Anglo-Saxon and Middle English were highly heterogeneous languages, even when only the literary forms are considered (compare the language of Beowulf with that of the Exeter Book in the Anglo-Saxon, or compare the original language of The Canterbury Tales with that of Piers Ploughman or of Sir Gawain and the Green Knight, all three of which were written in the late fourteenth Century).

As England became united and contact between dialect groups increased, some words from each dialect would survive but most would vanish, a process that has continued to this day. The literary language at any one time was a reflection of the region of medieval England which was dominant at that time. Either of these two factors would give the impression, judging only from the literary forms which have survived, that well defined shifts in pronunciation had taken place, whereas the changes that did occur were due to chance.

In order to show that a problem in "psycho-linguistics" exists and that the explanation is not trivial, one must show that:

- all dialects of the language, not merely the literary form, changed in the same direction at the same time

- all words in any one dialect with a particular vowel sound changed to another sound (for example, $\bar{a} \rightarrow \bar{q}$ )
- these changes were not related to political changes, especially with respect to the region of origin of the royal household.

Academisch Ziekenhuis,

John J. Pratt

Groningen, The Netherlands

\section{Tropical trees}

SiR,-May suggested (Nature, 257, $737-8 ;$ 1975) that "relatively stable tropical environment(s)" tend to produce plant species of high competitive ability (K-selected) as opposed to opportunists ( $r$-selected species) which he considers are favoured by "relatively vagarious, temperate climates". This generalisation is misleading. It overlooks the class of trees, also wellrepresented in tropical rain forest, known as pioneers which are opportunists. These are the species which colonise gaps. They possess a whole syndrome of features which equip them to this niche in the ecosystem.

In brief, they possess small, easily (wind or animal) dispersed seeds which have dormancy and are produced more or less continuously; are extremely fast growing, unable to regenerate under shade, and have pale wood of low density. Balsa (Ochroma lagopus) of Latin America is the classic example. Appreciation of the existence of two classes with strongly contrasting biology is vital to an understanding of both the ecology and silviculture of tropical rain forest. For example, it has been realised for some time that the most valuable African rain forests in which timber species of Meliaceae (African mahoganies) dominate are a late seral stage, not replacing itself but altering to a forest with less valuable and smaller trees of different families; and the Campnosperma and Terminalia forests which are the main natural resource of the Solomon Islands are stands of near-pioneers.

Pioneer species are the ones foresters nowadays mainly plant. Their biology and timber properties suit modern conditions. The humid tropics are wellsuited to rapid timber production and in fact tropical pioneer trees will be one of the world's main timber sources by the turn of the century. It is therefore important to correct any misconception that there are no pioneers in tropical rain forest.

T. C. WHITMORE

University of Oxford, UR 